A conversation with architects:

Paul Oliver and the anthropology of shelter

\author{
Marcel Vellinga \\ School of Architecture, Oxford Brookes University \\ Gipsy Lane Campus, Headington, Oxford OX3 OBP \\ mvellinga@brookes.ac.uk
}

Special Issue - Anthropology and Architecture: Misplaced Conversations

Abstract:

Throughout a career that spanned nearly 45 years, Paul Oliver consistently put forward his ideas on why an anthropological approach to architecture would be beneficial to the understanding of the design, use and meaning of buildings. This article intends to explore Oliver's views and writings on the relationship between architecture and anthropology. It aims to provide an overview of Oliver's oeuvre and approach, to position it in the context of other contemporaneous writings on architecture and anthropology, and to assess the influence of his work on later discourses. It will argue that, first and foremost, Oliver wrote for an architectural audience, rather than an anthropological one. Instead of wanting to engage in a direct dialogue about architecture with anthropologists, Oliver's main intention was to increase architects' awareness of the cultural embodiment of architecture. A better realisation of the intricate relation between architecture, society and culture would lead not just to a better understanding of why architecture takes the form it does but ultimately also to more culturally appropriate contemporary design. Oliver's main aim, then, was to make architects aware of the value and usefulness of anthropology, rather than to engage in a conversation with anthropology itself. The article concludes that Oliver's work remains as relevant to architectural discourse today as it ever was during the 45 years of his career.

Keywords: Anthropology; culture; Paul Oliver; society; vernacular architecture 


\title{
A conversation with architects:
}

\section{Paul Oliver and the anthropology of shelter}

\begin{abstract}
Anthropology is the study of man and Architecture the science of building. To propose as part of the education of every architect the Anthropology of Architecture seems far from unreasonable. ${ }^{1}$
\end{abstract}

\section{Introduction}

In 1979, while on a visit to several schools of architecture in Australia, Paul Oliver published a short article entitled "The anthropology of shelter". In it he tried to explain why, in his opinion, the study of anthropology should be included in architecture curricula. Anthropology, he wrote, as "the Study of Man", "... may throw light on the ways that he [Man] builds and shapes his settlements, the reasons why they take the forms that they do, and the way in which he uses and values them". ${ }^{2}$ Preferring to use the term "shelter" rather than "architecture" because the latter "has become a qualitative term, so that some buildings are deemed 'architecture' and others not", and drawing on brief case studies of Maasai, Mongol and Navajo building traditions, Oliver put forward the argument that the design, use and meaning of those and any other forms of architecture can only be understood when their respective cultural contexts are taken into account: "the relationships between the sexes, between the generations, living, dead and unborn"; "the mysteries and rites, myths and beliefs"; "the importance of tradition, custom, affinities to family, clan or people"; "the patterns of settlement as they reflect social structure". "Only by endeavouring to understand the values of the people can we get an insight into what shelter really means." ${ }^{3}$ To Oliver, anthropology offered the tools to reveal and understand those intricate ways in which architecture relates to cultural contexts, and thus, he concluded, it should be "far from unreasonable" to include it in the education of every architect.

"The anthropology of shelter" is not the only publication in which Oliver advanced this argument. Throughout a career that spanned nearly forty-five years, Oliver consistently put forward his ideas on why an anthropological approach to architecture would be beneficial to the understanding of the design, use and meaning of buildings. From his earliest publication on architecture, Shelter and Society, to his latest volume Built to Meet Needs: Cultural Issues in Vernacular Architecture, Oliver again and again repeated the call for an anthropological approach to the study of architecture. ${ }^{4}$ This article intends to explore Oliver's views and writings on the relationship between architecture and anthropology. ${ }^{5}$ It aims to provide an overview of Oliver's oeuvre and perspective, to position it in the context of other contemporaneous writings on architecture and anthropology, and to assess the influence of 
his work on later discourses. It will argue that, first and foremost, Oliver wrote for an architectural audience rather than an anthropological one. Instead of wanting to engage in a direct dialogue about architecture with anthropologists, Oliver's main intention was to increase architects' awareness of the cultural embodiment of architecture. A better realisation of the intricate relation between architecture, society and culture would not just lead to a better understanding of why architecture takes the form it does, but would ultimately also lead to more culturally appropriate contemporary design. Oliver's main aim then was to make architects aware of the value and usefulness of anthropology, rather than to engage in a conversation with anthropology itself.

\section{Architecture, society and culture}

In architectural circles, Paul Oliver is probably best known for his extensive body of work on vernacular architecture. The publication of the monumental Encyclopedia of Vernacular Architecture of the World (1997) cemented his reputation as one of the leading scholars in the field during the second half of the twentieth century, his name commonly being mentioned in the same breath as those of other influential scholars like Bernard Rudofsky, Amos Rapoport and Henry Glassie. ${ }^{6}$ But even before he edited the Encyclopedia, Oliver had already edited and authored several influential books on the topic, including the so-called Shelter series (Shelter and Society, Shelter in Africa, Shelter, Sign and Symbol and the little known Shelter in Greece [co-edited with Orestis Doumanis]) and Dwellings: The House Across the World; he had also already authored a substantial number of journal articles, book chapters and conference papers relating to vernacular architectural traditions from around the world. ${ }^{7}$ After the Encyclopedia he continued to publish on the subject, issuing a second, updated and expanded edition of Dwellings (now subtitled The Vernacular House Worldwide), a collection of articles and conference papers entitled Built to Meet Needs: Cultural Issues in Vernacular Architecture, and the Atlas of Vernacular Architecture of the World (with Marcel Vellinga and Alexander Bridge). ${ }^{8}$ Altogether, this work has done much to increase the understanding of the vernacular traditions of the world and to raise awareness in architectural circles of their value and importance; it also earned Oliver the accolade "vernacular man". 9

But Oliver's interests were in fact never limited to vernacular architecture only. Even before he began to publish on architecture in the late 1960s, he had already established himself as an influential scholar of blues music, having written some of the best-known and most widely referenced books on the subject, including Blues Fell This Morning: The Meaning of the Blues, Conversation with the Blues and The Story of the Blues. ${ }^{10}$ Indeed, as O'Connell notes, his influence in this field was such that "some writers have even referred to an 'Oliverian' tradition of blues scholarship" ${ }^{11}$ But by the early 1970s, Oliver decided to take a break from blues scholarship; a decision that allowed him to turn his attention to other fields of interest, most notably architecture. ${ }^{12}$ Although he never trained as an architect but 
as an artist and art historian, Oliver's interest in architecture had already been awoken early on in his teenage years, when his father, the architect William Richard Norman Oliver, used to take him on site visits and introduced him to a range of architectural writings. ${ }^{13}$ In the early 1960s, Oliver had the opportunity to further develop this personal interest when, as a trained art teacher, he was offered the post of "drawing master" at the Architectural Association (AA). The diversity of programmes on offer at the AA the time, run by such prominent architects and theorists as Cedric Price, James Stirling, Peter Cook and Otto Königsberger, invigorated his interest in architecture and exposed him to a wide range of approaches and styles, all of which he engaged with enthusiastically, despite his lack of formal architectural education. A visit in 1964 to Ghana, where he briefly studied Gurunsi, Tallensi and Asante settlements, further stimulated his interests. ${ }^{14}$

Although Oliver was always fascinated by the domestic "folk" architecture of the UK and France and the building traditions of other, non-Western peoples and cultures, this "vernacular" architecture was not his only area of architectural interest. When asked in the early 1960s to run the "History of Architecture" course at the AA, he introduced a lecture series on the "History of the Modern Movement" alongside the more conventional architectural history course offered until then. In the late 1970s and early 1980s, he studied and wrote about the British suburban developments of the 1920s and 1930s, arguing for the significance and worth of a "conspicuously neglected" part of British architectural, planning and social history. ${ }^{15}$ Later still, in 1990, he authored Architecture: An Invitation (with Richard Hayward), in which he wrote about an "architecture for all" and drew attention to architectural forms as diverse as Oxford colleges, Norman Foster's Sainsbury building and the gecekondu squatter settlements in Turkey. ${ }^{16}$ In all of this work, Oliver's aim was to draw attention to the ways in which all forms of architecture (be they architect-designed, vernacular, popular, informal or commercial) are intricately linked to aspects of society and culture like economic structures, social relationships, political formations and religious values. This objective appears to be the main reason for Oliver's engagement with anthropology (apart, that is, from his own personal interest in the arts, music and other traditions of "other" peoples and cultures). ${ }^{17}$ In Oliver's view, it is only by investigating the way in which buildings (any buildings) embody social identities, symbolic messages, cultural values and economic relationships that a true understanding of the form, use and meaning of architecture can be arrived at. Anthropology, as the study of human cultural diversity, offers the theories, concepts and methods to help arrive at this understanding.

Oliver's interests thus extended beyond the field of vernacular architecture studies (when defined as the study of traditional, indigenous, folk or popular building traditions that have come about without the involvement of architects). The importance of cultural embodiment that he writes about certainly applies to those kinds of building traditions, but it similarly does to all other forms of architecture (capital " $A$ " or otherwise) not commonly identified as vernacular that feature in his publications. It is no doubt for this reason that for a long time (until he started working on the Encyclopedia, that is), Oliver appears to have been 
undecided about the appropriateness of the term "vernacular". In his earlier publications in particular, he discussed its adequacy at some length, pointing to the difficulties surrounding the meaning of the term and frequently adding quotation marks when he used it. In 1979, for example, he noted how "so general a term is only of limited value", and added that he was working on a more useful terminology. ${ }^{18}$ His hesitation to adapt the term thus seems to have been caused by the fact that he saw it as limiting in its scope, as well as difficult (if not impossible) to define. ${ }^{19}$ Well into the 1980s, in fact, he preferred to use the term "shelter" in both his writings and teaching because it "describes an element common to all, or nearly all, buildings". 20 "What it [the term 'vernacular'] embraces is not, in my view, the breadth of field that is potentially within the Anthropology of Shelter", he wrote in 1979.

Although the accolade "vernacular man" is thus somewhat misleading, Oliver did nonetheless tend to limit his focus to non-monumental, non-formal and non-architect designed works. Concerned about the fact that most architectural writings took as their subject "the edifices that housed the principal actors in formal history" and that are "erected to provide lavish, unused spaces for the mightily privileged few", he used his publications to call upon the field of architecture to take seriously the diverse forms of architecture that had conventionally been beyond the scope of the architectural canon. ${ }^{21}$ No doubt influenced by the social history writings popular during the 1960s and 1970s, as well as perhaps by the social revolutionary spirit of the times more generally, he called attention to those building traditions that "do not embody the omnipotence of the tyrant or the adoration of a people as the castles and the temples of the world may do", but that are nonetheless a tangible, fundamental and valuable part of the world's built heritage and that should thus not be dismissed or ignored: the traditional farmhouses of Europe and North America; the indigenous building traditions of non-Western peoples; the informal settlements in the fast-growing cities around the world; and the alternative ways of building (such as Californian "funk" dome architecture) that feature prominently in his major publications. ${ }^{22}$ From Oliver's perspective, as architectural expressions of the societies and cultures that produced them, these buildings deserved as much recognition as any palace, cathedral or mansion designed by an architect for an elite.

\section{Inclusivity and engagement}

In all his work Oliver thus called for an inclusive perspective on architecture that recognises the diversity of building traditions from all around the world and that tries to understand this diversity by studying the intricate relationships that exist between architecture and the societies and cultures that produce it. In so doing, he was of course never alone. When he began his work on architecture during the 1960s and 1970s, a large number of authors were interested in similar issues. Indeed, in retrospect, it is possible to identify this period of time as a pivotal one in the development of what would later become known as the field of international vernacular architecture studies; the period when the influence of Rudofsky's 
Architecture Without Architects was felt most strongly and when Amos Rapoport, Labelle Prussin, Rene Gardi, Norbert Schoenauer and Enrico Guidoni, to name but a few, published seminal works on "traditional", "indigenous" and "primitive" forms of architecture. ${ }^{23}$ At the same time, it was a period that saw influential publications that criticised the social failings of modernism and its associated discourses. ${ }^{24}$ No doubt these contemporaneous scholarly debates stimulated Oliver's engagement with the study of architecture; as much so, it would seem, as his father's encouragement in earlier years, the influence of his colleagues at the $A A$, his experiences in Ghana and his personal decision to take a break from his blues research. Conversely, Oliver's substantial and fundamental contribution to this emerging discourse is beyond question. In later decades, up until today, many other scholars have taken a similar approach to architecture as Oliver and his contemporaries; sometimes on a global, cross-cultural and comparative scale like Oliver himself, but more commonly from a regional or national perspective. ${ }^{25}$ Many of those later authors have been directly influenced by Oliver and, like him, have aimed to call attention to building traditions outside of the architectural canon, while simultaneously illuminating the many ways in which architecture is intricately related to culture and society.

Inevitably, Oliver's work shows overlaps with that of his contemporaries. His call for a more inclusive perspective on architecture, for instance, was shared by Rudofsky, even if Oliver profoundly disagreed with the latter's aesthetic and romanticist approach to the subject. ${ }^{26}$ With Rapoport he shared his interest in the cultural embodiment of architecture; on the whole, however, Oliver's work was more ethnographic and descriptive than Rapoport's theoretical and at times rather abstract approach. His global and cross-cultural perspective was similar to Rudofsky, Rapoport and Guidoni, but quite different from, for example, Prussin and Gardi, both of whom focused on African traditions only. What characterises Oliver's work most when considered in its entirety is its volume (he edited and [colauthored eleven books on architecture during the period 1969 until 2007, in addition to many articles and book chapters), its cross-cultural and comparative scope, and its thematic consistency. From his earliest publication, Shelter and Society, all the way to his last public lecture at the Royal Institute of British Architects in 2010, Oliver again and again reminded his audience of the need to look beyond the architectural canon and to study buildings in their cultural and social context. ${ }^{27}$ Over and again he used examples of cultures and building traditions from around the world to illustrate and support his arguments: from the Navajo hogan to the Maasai enkang; from the Shakers' meeting houses to the Inuit iglu; and from the Maori whare to Tuareg tents. Invariably also, he would continue to remind his audience of the need for an anthropological approach to the study of architecture.

Oliver first argued for the value of anthropological theory to the study of architecture in his introduction to Shelter and Society. Discussing the various terminologies used to describe the field of study he is interested in (vernacular, traditional, indigenous), he quoted Claude Lévi-Strauss to support his challenge to the notion that the architectures concerned were somehow "primitive" and that generalisations about their supposed static nature could 
therefore be made: "But is such a generalisation valid? ... Some anthropologists would contend that we cannot [assume a 'primitive' world without change, evolution or decline]." ${ }^{28}$ His initial engagement with anthropology was thus motivated by a wish to broaden the scope of rather ethnocentric architectural perspectives and discourses; to learn from theory developed in another academic discipline to advance knowledge and understanding in architecture. In his subsequent publication, Shelter in Africa, he reaffirmed the need for such interdisciplinary knowledge exchange: "It would seem that the most valuable contribution that anthropologists could make to the study of African vernacular architecture would be to show the relationships between their areas of study and the buildings, villages, communities and cities in which they take place. ${ }^{29}$ But he also lamented that up until then anthropologists had shown too little interest in architecture to actually make such a contribution. Citing Marcel Griaule's work in Mali as an exception, he noted how the British school of anthropology, including A.R. Radcliffe-Brown, E.E. Evans-Pritchard and the "great" Bronislaw Malinowski, had been too occupied with issues of kinship and inheritance to pay sufficient attention to architecture. ${ }^{30}$ Consequently, although both disciplines could complement one another, communication between the two had been limited.

In his subsequent publications, Oliver repeatedly raised the same issues. The understanding of the cultural embodiment of architecture would benefit, he argued, from an active engagement with anthropology, for example in the case of a study of the symbolism inherent in buildings; but differences in perspective and methodology and a mutual lack of interest among the disciplines meant that the "anthropology of shelter" remained "in its infancy". ${ }^{31}$ In Dwellings he noted how "anthropological enquiry is not a customary part of architectural education, and an understanding of architectural principles has never been considered a significant part of the training of an anthropologist", even though "potentially, it is from interdisciplinary work that the most rewarding results could be obtained". ${ }^{32} \mathrm{He}$ repeated this point in subsequent publications, including "The anthropology of shelter" and Architecture: An Invitation; adding rather critically in the latter book that anthropologists' resistance "to using their skills in any applied way to advise on the improvement of conditions" plays a significant part in this. ${ }^{33}$ In the introduction to the second edition of Dwellings, however, he noted that "slowly the position is changing", as more conferences and publications on the subject (by both architects and anthropologists) had begun to emerge from the 1990 s onwards. ${ }^{34}$ Still, in the epilogue, he commented on the difficulty of obtaining the information generated as part of this increased interest, "available only in specialised professional publications, or in monographs of limited circulation", and he again called for "dialogue, exchange of information and research and, above all, joint research". ${ }^{35}$

From the late 1980s onwards, Oliver's work moves beyond academic concerns with the cultural embodiment of architecture and the inclusivity of the architectural discourse that characterises his early Shelter books, and begins to be characterised by a more direct engagement with contemporary social issues. In his introduction to the first edition of 
Dwellings, he emphasised that the study of the relationship between architecture, society and culture is not just necessary to arrive at a better understanding of architectural traditions, but is fundamental in order to meet the future housing needs of the world. ${ }^{36}$ In a time of unprecedented population growth and social and environmental change, the cultural values of societies need to be taken into account if the provision of housing is "to mean more than the mere emergency provision of roofs and walls". ${ }^{37}$ In subsequent years the issue of housing the world becomes a major concern that sets the context for most, if not all, of Oliver's writings. In the second edition of Dwellings, he elaborated on his concerns in a new epilogue and encouraged architects to take on a role of "enabler", working on-site in an advisory capacity with the members of a local community rather than from a remote distance on large-scale projects. ${ }^{38}$ Similar calls are found in his other work, including Built to Meet Needs and the Encyclopedia, where he noted that "the solution to the world's housing demands will only be met, I believe, in the forthcoming century, through the support, enhancement and adequate servicing of vernacular architecture". ${ }^{39}$ At this late stage in his career, Oliver continued to call for an anthropological perspective on architecture and for anthropologists to become more involved in architecture: "Anthropologists can tell us much more about the intangible abstractions of cultures". ${ }^{40}$ But it becomes especially clear that, above all, Oliver is seeking a conversation with architects, as the use of the word "us" in the quote indicates. In all his later work, he continued to remind architects in particular that an understanding of the cultural embodiment of architecture will lead to better design and ultimately to a better quality of life for those who use it.

\section{An architectural approach}

Oliver's concern with the practical application of knowledge about the cultural context of architecture indicates how his perspective, although drawing on anthropological theory, has always been different from that of most anthropologists. To the latter, the study of architecture has tended to provide "a way into" a society or culture. By studying architecture (its form, its spatial layout, its decorations), the anthropologist is able to get a better understanding of the social relationships, cultural values and symbolic meanings that give rise to a particular form of architecture. The ultimate aim of the anthropologist's engagement with architecture has commonly been the improved understanding of this cultural context. Oliver's perspective, however, is a different one; it is that of an architect or an architectural historian, rather than that of an anthropologist. To Oliver, the social relationships, cultural values and symbolic meanings are not so much important in their own right, but of interest and value because they explain why the architecture concerned takes on the form it does. They should be studied because they "throw light on the ways that he [Man] builds and shapes his settlements, the reason why they take the forms that they do, and the ways in which he uses and values them". ${ }^{41}$ The understanding of culture, in Oliver's approach, is thus not the objective, but a means to understand the architecture, as well as 
to inform future design related to it. ${ }^{42}$ The architect needs to know about economic relationships, social structures or religious values because by doing so, s/he will learn why a building has the spatial layout it does, why specific materials or technologies have been used in its construction, or why a particular decorative feature has a symbolic meaning; knowledge that will "eventually lead to the design of buildings that are an appropriate focus for human values" ${ }^{43}$ Culture in this approach is "a way into" architecture; the converse, that is, of the anthropologist's concern.

This different starting-point is reflected in Oliver's body of work. As noted above, his writings take the form of a dialogue with architects, in which he continuously urges the latter to look beyond the bricks and mortar of a building to its social, economic and cultural context. A similar attempt to communicate directly with anthropologists so as to make them aware of the value of architecture and the importance of studying materials, forms, technologies and plans cannot be found in his work. Even though he regularly commented on the failure of both disciplines to collaborate, he himself (in his writings at least) never appears to have made an effort to directly communicate with anthropologists either. He never published articles in anthropological journals or chapters in books edited by anthropologists, while his books were commonly published by architectural presses and invariably included in publishers' architecture lists. The only time he collaborated directly with anthropologists was when he included their work in his edited publications, in particular the Encyclopedia. ${ }^{44}$ Despite consistently engaging with anthropology, Oliver's intended audience was thus first and foremost architectural. In the main, he did not really engage in a true dialogue with anthropologists; his engagement with anthropology remained more of a one-way affair in which he drew on anthropological theory in order to further architects' (and his own) understanding of the cultural embodiment of architecture. In effect, Oliver's was a conversation with architects about anthropology, rather than a conversation with anthropology. Perhaps this is the reason why Oliver's work, although commonly acknowledged and referenced, does not take a prominent place in contemporary anthropological writings on architecture. ${ }^{45}$

That Oliver's perspective and approach is fundamentally an architectural one is apparent from his methodology. Oliver's engagement with anthropology has always been largely theoretical. He never undertook fieldwork in an anthropological sense; that is, he never stayed in a village or community for a long period of time, drawing and photographing its buildings, observing and interviewing its members, and participating in everyday or ceremonial activities. Participant observation, the principal ethnographic method when Oliver was doing his research, was never part of his methodology. Yet Oliver was no "armchair anthropologist" either. During his career, he visited more than seventy countries in all continents. During these trips he avidly documented the building traditions he encountered; visiting towns and villages, talking to people he met on the road, making notes and taking $35 \mathrm{~mm}$ slides wherever he went. ${ }^{46}$ He spent several months at a time in some places, such as the United States (where his research was mainly focused on the blues), 
Ghana (to teach at the University of Kumasi), Turkey (where he undertook work on postdisaster resettlement) and Iran (to document architecture and life in the bazaar at Isfahan). Other countries, such as France and Spain, he visited on a regular basis, but for much shorter periods of time. Yet most countries, like Indonesia, Brazil or China, he visited only once or twice, often combining his visits with an attendance at conferences or workshops. So while Oliver never stayed in the same place for a sustained period of time or immersed himself into the architecture of a specific community in the way that an anthropological approach would require, his travels to most corners of the world nonetheless allowed him to get a first-hand experience of the architectural characteristics and cultural contexts of a large variety of disparate building traditions.

Photography was one of the main methods by which Oliver documented architecture. During all his travels, he took slides of landscapes, buildings and architectural details like materials, forms, functions and technologies, carefully noting down on the slide mounts details of what the slides showed. ${ }^{47}$ For many (though by no means all) trips he also kept notebooks and diaries in which he would record details of the journeys, such as the places visited, the names of informants, guides or translators, and the specific buildings, customs, materials or traditions that he had observed. Every now and then, he would make simple sketches of floor plans or elevations. In the main, however, drawing never was a major part of his field research methods, even though he was an accomplished draughtsman and drawing played an important part in his early blues publications. ${ }^{48}$ Most architectural drawings that he made were done specifically for publications, sometimes years after he visited the buildings concerned. Back home, Oliver would supplement the information he collected in the field with data he found in literature. During the course of his career, he built up an extensive multi-disciplinary collection of books, journals, conference papers and dissertations that comprises the works of not just architects and anthropologists, but also of geographers, (architectural and art) historians, folklorists and archaeologists. The information he obtained from these works enabled him to verify, compare and contextualise the knowledge he gained during his frequent fieldtrips and also made it possible for him to develop his characteristic cross-cultural and comparative perspective on the study of architecture.

Although he curated a number of exhibitions on architecture during the 1970s, Oliver communicated his work mainly through his writings, especially his books. ${ }^{49}$ An eloquent and prolific author, he developed a distinctive style of writing that can be found in all his publications. Drawing on the range of sources available (the photographs, the notes, the literature), he would usually focus on one main theme (the role of symbolism, say, or the transmission of tradition) and use case studies of specific cultures and building traditions to illustrate and support it. In the main, the case studies constitute brief ethnographic descriptions that detail landscapes, settlement patterns, materials and technologies, or building processes, and they invariably emphasise how those are intricately related to customs, norms and beliefs. They are short ethnographic sketches that not only serve to 
document and show how the particular architecture forms a logical part of the cultures concerned, but also aim to show to the reader that the same aspect (the role of symbolism, or the transmission of tradition) will manifest itself in divergent but fundamentally similar ways in different architectures around the world. In a classic anthropological way, he thus uses the ethnographic data that is available to him to support his more general theories about the intricate relationship between architecture, society and culture. In addition to providing ethnographic insights into the building traditions of specific peoples and cultures, the case studies thus serve as an effective means to introduce the cultural embodiment of architecture to an architectural audience that is seldom exposed to this kind of architectural diversity.

\section{Structural-functionalist representations}

Throughout his career, Oliver referenced the work of a range of prominent early and midtwentieth century anthropologists, including Franz Boas, Bronislaw Malinowski, A.R. Radcliffe-Brown and, in particular, Claude Lévi-Strauss. As such, his range of anthropological sources and influences is theoretically and methodologically eclectic. Nonetheless, despite this wide range of influences, his work can perhaps best be described as broadly structuralfunctionalist in character. In conceptualising the relationship between architecture, society and culture, Oliver emphasises how different peoples around the world build and dwell in different forms of architecture and how we can only understand these unique and distinct forms of architecture if we see them as an integral part of the societies and cultures that produced them. Architecture, "built to meet needs", plays a fundamental role in maintaining general social and cultural norms, customs and needs that go beyond those of the individual members of the societies concerned. It has a function in society among all peoples in the world and only by identifying this function can its form, meaning and use be understood. "Shelter", Oliver writes, "is built to serve its purpose" and its builders work within the limitations of customs, norms and traditions. ${ }^{50}$ From this structural-functionalist perspective, architecture, society and culture have an independent existence, regardless of human agency; they are place specific, clearly bounded and potentially fixed in their nature. It is a perspective that can be found in Oliver's earlier Shelter works, but it also helps to structure Dwellings and, most obviously, underpins the classification system based on cultures and culture regions that he used to structure the Encyclopedia.

As a result of this structural-functionalist premise, his ethnographic case studies sometimes appear rather essentialist. O'Connell has noted how Oliver's writings on the blues sometimes blurred the lines between imagination and reality because of the fragmented nature of his sources, resulting in partly imaginary (and sometimes romanticised) accounts that present a more absolute and coherent picture than the sources actually allowed for. ${ }^{51}$ The same may arguably be said of some of the ethnographic cases used in his architecture writings. Commonly based on data that had been collected in a somewhat piecemeal 
manner (combining information from field visits with photographs and published literature), sometimes over extended periods of time, Oliver's descriptions tend to be written in the ethnographic present and to be rather definite in its statements. Thus, for example, he writes confidently about "the Maasai woman", who builds her own house, but who "works within fairly tight limitations nonetheless, so that the resultant house is indisputably Maasai and traditional"; or about "the Navajo", who "from the entrance of his hogan ... faces the rising sun, and with arms raised, sings 'There beneath the sunrise, built of dawn's first light, built of fair white corn, stands the hogan, the hogan blessed'". ${ }^{2}$ Many similar instances can be found in his other publications. In such representations, not only is the individual clearly subservient to a culture that determines and delimits his actions; both are also represented in an essentialist manner (the Maasai woman, the Navajo man) that leaves little scope for individual agency, regional diversity or historical change. The people (builders and users) in Oliver's representations are passive and in the main simply follow traditions. Furthermore, although the representations expose the architectural reader to rich ethnographic descriptions of architectural traditions, they risk emphasising and romanticising the "otherness" of the peoples and buildings concerned; as when he concludes that the processes that characterise the Maasai culture of building ("functionalism, or fitness for purpose, or human scale and humane environments") is "far removed from those that we use" ("we" presumably referring to Western architects). ${ }^{53}$

However, despite the absolute and essentialist tone of many of his writings, Oliver always recognised the dynamic and fluid nature of architectural traditions, as well as the crosscultural borrowing that takes places between them. In Shelter and Society, he already noted that "concentration on the purely indigenous diverts consideration from the cross fertilisation of ideas, the infiltration of technology and the changing social needs of a society $(\ldots)^{\prime \prime}{ }^{54}$ In his later work, he pays much attention to such processes of cross-fertilisation and interconnection and the changing social needs that accompany them, focusing on topics like the transmission of tradition and the complexities surrounding the transfer of technologies from one culture to another. ${ }^{55}$ By no means, therefore, does he present cultures and architectural traditions as completely isolated and fixed. Nevertheless, a tendency to decry change and development as a result of external cultural contact and interference can regularly be found in his writings. For example, in the case, once more, of the Maasai, he writes about how the enkang is the focus of those aspects of tribal and social life that "keep the Maasai united in the face of westernisation". In his later work in particular, he frequently writes about the effects of modernisation and globalisation on vernacular architecture in negative terms, decrying the neglect, abandonment and destruction that often befalls the traditions. ${ }^{56}$ Like many of his contemporaries, Oliver had a tendency to distinguish "true" and "authentic" vernacular traditions that existed in pre-colonial or premodern periods from later "modernised" or "hybrid" variations; and to prioritise the former over the latter. ${ }^{57}$ Thus although he was interested in modernity and contemporary forms of 
architecture, he would see them as fundamentally different from vernacular architecture and consequently he discussed them in separate publications. ${ }^{58}$

Of course Oliver was not alone in representing cultural diversity and vernacular architecture in this manner. Up until the 1980s, essentialist descriptions of other cultures that confidently represented customs, beliefs, values and practices were common in anthropological writings, including those of the authors that Oliver frequently referred to, like Lévi-Strauss and Malinowski. Many of the anthropological writings on architecture that appeared during the time that Oliver was active described building traditions in similar essentialist terms as Oliver; even if they commonly were more interested in the cultural embodiments and paid less attention to the architecture (the materials, the forms, the structural systems) itself. ${ }^{59}$ Like Oliver, they often assumed that the societies, cultures and architectures concerned had an independent existence, regardless of human agency; and that the traditions they documented and analysed were place specific and had often remained unchanged for long periods of time. It is only after the 1980s, when essentialist and static anthropological representations had become a serious matter of debate through the work of authors like Fabian, Marcus and Fischer, and Clifford, that different works that paid more attention to the existence of cultural variation, to processes of change, to consumption and to the role of human agency in them began to emerge. ${ }^{60}$ By that time, however, Oliver had already formally retired and was editing his monumental Encyclopedia; he never had the time or opportunity to truly catch up with those theoretical developments and to incorporate them in his work.

\section{Paul Oliver's legacy}

Paul Oliver's contribution to the field of international vernacular architecture studies is significant and manifold. As a researcher and author, he has demonstrated the value of a cross-cultural and comparative approach to the study of architecture, urging architects to look beyond the narrowly defined boundaries of the architectural canon to value and engage with non-monumental, non-Western and non-architect designed building traditions, and to consider all architecture in its social and cultural context. As an editor, he has published a number of pioneering and influential works that have helped to define and validate the field of international vernacular architecture studies and brought together and made visible the work of large numbers of scholars. As a teacher and educator, he has inspired several generations of students, teaching them how to study the architectural traditions of the world within their cultural contexts and how to creatively, meaningfully and responsibly integrate them in contemporary architectural design in order to face up to current social, economic and environmental challenges. ${ }^{61}$ His main objectives throughout all this have been to celebrate the diversity, richness, ingenuity and variety of the world's architectural traditions, to elucidate how they are intricately and meaningfully related to societies and cultures, and to remind architects that they can make a difference if they 
acknowledge and engage with them. The anthropology of shelter approach that he consistently called for has always been central to his endeavours.

Looking at the scope and content of the field of international vernacular architecture studies today, it can be argued that Oliver's objectives have largely been met. Most work in the field engages architectural traditions within their social and cultural contexts, and the application of vernacular knowledge in contemporary design has become an area of increased interest in recent years. The engagement of anthropologists in the field has grown, while ethnographic research methods are regularly employed by architects studying the vernacular architecture of the world. Most of those working in the field, be they architects, anthropologists, geographers or otherwise, acknowledge the influence that Oliver's writings and approach have had on their own work.

Beyond the field of vernacular architecture studies, however, in architecture more generally, his influence is more difficult to ascertain. That architecture needs to be studied and understood in its social and cultural context is by now commonly accepted; but at the same time the tendency to focus on a restricted number of architect-designed buildings and to treat them as objects of art independent of their social and cultural context is still prevalent. Oliver's direct impact in contemporary architectural design or in related fields he wrote about (such as housing and conservation) is hard to work out; his work is rarely cited or mentioned in standard publications related to those subjects.

In a similar vein, his influence on anthropology is difficult to pin down. The last few decades have seen a notable increase in anthropological studies of architecture. ${ }^{62}$ Although most of those studies pay homage to Oliver's work, many of them in fact show limited interest in the architectural (material, technological, structural) elements of the building traditions concerned, focusing instead on the social and symbolic aspects. ${ }^{63}$ At the same time, collaborations between anthropology and architecture are still rare; few joint conferences are organised and few joint publications exist, while architecture is still rarely included in anthropological curricula and not many architects are taught anthropology as part of their education. $^{64}$

Thus, despite the fact that Oliver's work remains as relevant to architectural discourse today as it ever was during the forty-five years of his career, his actual influence beyond the discourse on vernacular architecture, in the fields of architecture and anthropology more generally, for now remains to be explored.

\footnotetext{
1 Paul Oliver, "The Anthropology of Shelter", in Michael Keniger (ed.), Market Profiles (Conference Proceedings, University of Queensland, 1979), 9. I am grateful to the editor and the anonymous reviewer for their comments on an earlier draft of this article.

2 Oliver, "The anthropology of shelter", 9.

${ }^{3}$ Oliver, "The anthropology of shelter", 14.
} 
${ }^{4}$ Paul Oliver, ed., Shelter and Society (London: Barrie and Rockliff, 1969); Paul Oliver, Built to Meet Needs: Cultural Issues in Vernacular Architecture (Oxford, Architectural Press, 2006).

${ }^{5}$ Throughout his career, Oliver used and discussed a range of different terms to identify his subject matter, including "shelter", "architecture", "vernacular architecture" and "dwelling". He never seemed able to decide on which of them was the most appropriate, although at the end of his career, after he had finished the Encyclopedia of Vernacular Architecture of the World, he seemed to favour "vernacular architecture". For ease and consistency, the term "architecture" is used in this article.

${ }^{6}$ Paul Oliver, ed., Encyclopedia of Vernacular Architecture of the World (Cambridge: Cambridge University Press, 1997).

${ }^{7}$ Oliver, Shelter and Society; Paul Oliver, ed., Shelter in Africa (London: Barrie and Jenkins, 1971); Paul Oliver, ed., Shelter, Sign and Symbol (London: Barrie and Jenkins, 1975); Paul Oliver and Orestis Doumanis, eds, Shelter in Greece (Athens: Architecture in Greece Press, 1974); Paul Oliver, Dwellings: The House Across the World. (Austin: University of Texas Press, 1987).

${ }^{8}$ Paul Oliver, Dwellings: The Vernacular House Worldwide (London: Phaidon, 2003); Oliver, Built to Meet Needs; Marcel Vellinga, Paul Oliver and Alexander Bridge, Atlas of Vernacular Architecture of the World (London: Routledge, 2007).

${ }^{9}$ Charles Knevitt, "Vernacular Man”, Architects Journal, 22 January 1998: 24-25.

10 Paul Oliver, Blues Fell This Morning: The Meaning of the Blues (London: Cassell, 1960); Paul Oliver, Conversation with the Blues (London: Cassell, 1965); Paul Oliver, The Story of the Blues (London: Barrie and Rockliff, 1969).

${ }^{11}$ Christian O'Connell, Blues, How Do You Do? Paul Oliver and the Transatlantic Story of the Blues (Ann Arbor: University of Michigan Press, 2015), 1.

12 One of the reasons for this decision was that by that time most of the blues singers that he was interested in had passed away (Oliver, personal communication). O'Connell notes that Oliver has always been less interested in the commercialised "revival" blues that appeared in the 1950s and 1960s and that formed the inspiration for white pop and rock musicians at the time.

${ }^{13}$ Richard Norman Oliver trained as an architect at the Regent Street Polytechnic and specialised in cinema design during the 1920s and 1930s. During the Second World War he worked for the War Office, where he focused on the design of temporary hospitals and fire stations and was involved in post-bombing reconstruction work. In May 1942, aged 15, Oliver assisted his father in documenting the bombing of Exeter. The experience made a large impression on him and triggered his interest in post-disaster shelter (Oliver, personal communication).

${ }^{14}$ Oliver, Encyclopedia, vii.

${ }^{15}$ Paul Oliver, Ian Davis and Ian Bentley, Dunroamin: The Suburban Semi and its Enemies (London: Pimlico, 1981).

${ }^{16}$ Paul Oliver and Richard Hayward, Architecture: An Invitation (Oxford: Basil Blackwell, 1990).

${ }^{17}$ As a young man, Oliver had contemplated studying social anthropology, but he was not able to do so due to the fact that he had not read Latin at school. He decided on art instead (Oliver, personal communication). His interest in "other" peoples and cultures is also reflected in the extensive collections of ethnic art and world music that he compiled during his lifetime.

${ }^{18}$ Oliver, Built to Meet Needs, 4.

${ }^{19}$ In his introduction to Dwellings, Oliver briefly discusses the different terms that have been used to describe buildings not designed by architects, including "vernacular", "indigenous", "popular" and "primitive". He refers to each term as creating "artificial, and generally insupportable, distinctions" (Oliver, Dwellings: the House Across the World, 9).

${ }^{20}$ Oliver, "The anthropology of shelter", 9. In his later publications, however, such as Dwellings and the Encyclopedia, he noted that this term is "inadequate" as well, because it carries "connotations of the rudimentary and the temporary". Oliver, Encyclopedia, xxi; Oliver, Dwellings: The House Across the World, 9.

${ }^{21}$ Oliver, Shelter and Society, 7.

${ }^{22}$ Oliver, Shelter and Society, 12. O'Connell notes that an acknowledgement of the volatile civil rights context characterised by protests, boycotts and sit-ins in which Oliver carried out his blues research in the USA in 1960 is conspicuously lacking in his writings on the blues and African American culture. To what extent political and social contexts influenced his architectural work is difficult to establish. O'Connell, Blues How Do You Do?, 112-15).

${ }^{23}$ Bernard Rudofsky, Architecture Without Architects: A Short Introduction to Non-Pedigreed Architecture (London: Academy Editions, 1964); Amos Rapoport, House Form and Culture (Englewood Cliffs, NJ: Prentice- 
Hall, 1969); Labelle Prussin, Architecture in Northern Ghana: A Study of Forms and Functions (Berkeley: University of California Press, 1969); Rene Gardi, Indigenous African Architecture (New York: Van Nostrand Reinhold, 1974); Norbert Schoenauer, Introduction to Contemporary Indigenous Housing (Montreal: Reporter Books, 1973); Enrico Guidoni, Primitive Architecture (New York: H.N. Abrams, 1975). Bernard Rudofsky's Architecture without Architects exhibition was first shown at the Museum of Modern Art in New York in 1964. The exhibition and its associated catalogue played an important part in instigating the increased academic interest in non-Western vernacular architecture that is noticeable during the 1960s, even though the extent to which his work has actually influenced the further development of the field of international vernacular architecture studies is difficult to ascertain. See Marcel Vellinga, "A 'therapeutic irritant': Bernard Rudofsky and the vernacular", in Mar Loren and Yolanda Romero, eds, Bernard Rudofsky: Desobediencia Critica a la Modernidad (Granada: Centro Jose Guerrero, 2014).

${ }^{24}$ For example Jane Jacobs, The Death and Life of Great American Cities (New York: Vintage Books, 1961); Herbert J. Gans, The Urban Villagers: Group and Class in the Life of Italian-Americans (New York: Free Press of Glencoe, 1962); Robert Venturi, Denise Scott Brown and Steven Izenour, Learning from Las Vegas (Cambridge, MA: MIT Press, 1972).

${ }^{25}$ Colin Duly, The Houses of Mankind (London: Thames and Hudson, 1975); Kaj Andersen, African Traditional Architecture: A Study of the Housing and Settlement Patterns of Rural Kenya (London: Oxford University Press, 1977); Susan Denyer, African Traditional Architecture: A Historical and Geographical Perspective (New York: Africana Pub, 1978); Ronald G. Knapp, China's Traditional Rural Architecture, A Cultural Geography of the Common House (Honolulu: University of Hawai'i Press, 1986); Roxana Waterson, The Living House: An Anthropology of Architecture in South-East Asia (Singapore: Oxford University Press, 1990).

${ }^{26}$ Oliver has noted that he decided to publish Shelter and Society in response to Rudofsky's Architecture Without Architects because he was dissatisfied with the latter's aesthetic and formal approach and its emphasis on the buildings as art objects (Oliver, Encyclopedia, vii).

${ }^{27}$ Oliver's last public lecture was the opening address for the "Djenné: African City of Mud" exhibition curated by Trevor Marchand at the Royal Institute of British Architects in 2010.

${ }^{28}$ Claude Lévi-Strauss, Structural Anthropology (New York: Basic Books, 1963); Oliver, Shelter and Society, 9.

${ }^{29}$ Oliver, Shelter in Africa, 13.

${ }^{30}$ Marcel Griaule and Germaine Dieterlen, "The Dogon of the French Sudan", in C.D. Forde, ed., African Worlds: Studies in the Cosmological Ideas and Social Values of African Peoples (Oxford: Oxford University Press, 1954).

${ }^{31}$ Oliver, Shelter, Sign and Symbol, 34.

32 Oliver, Dwellings: The House Across the World, 9.

${ }^{33}$ Oliver and Hayward, Architecture: An Invitation, 144.

${ }^{34}$ Oliver, Dwellings: The Vernacular House Worldwide, 14. Examples include the International Association for the Study of Traditional Environments (IASTE) conferences, the International Association People-Environment Studies (IAPS) conferences, and the TERRA conferences.

${ }^{35}$ Oliver, Dwellings: The Vernacular House Worldwide, 262-63.

${ }^{36}$ To emphasise this point, Oliver had made sure the publication coincided with the United Nations' International Year of Shelter for the Homeless.

${ }^{37}$ Oliver, Dwellings: The House Across the World, 15.

${ }^{38}$ Oliver, Dwellings: The Vernacular House Worldwide, 263.

${ }^{39}$ Oliver, Encyclopedia, viii.

${ }^{40}$ Oliver, Built to Meet Needs, 180.

${ }^{41}$ Oliver, "The Anthropology of Shelter", 9.

42 Oliver himself was very aware of this difference in approach and discusses it at some length in the introduction to Shelter and Society.

${ }^{43}$ Oliver, "The Anthropology of Shelter", 9.

${ }^{44}$ Shelter and Society, Shelter in Africa and Shelter, Sign and Symbol each include one contribution by an anthropologist; the Encyclopedia includes many such contributions. Although Oliver is a Fellow of the Royal Anthropological Institute, this was the result of his work in the field of blues and African American music.

${ }^{45}$ Although Oliver's work has been favourably reviewed in anthropological circles (for example Caroline Humphrey, "No Place Like Home in Anthropology: The Neglect of Architecture”, Anthropology Today 4, no. 1 (1988): 16-18; Jonathan Benthall, "The Small Habitation", Anthropology Today 14, no. 2 (1998): 1-2), his work is not discussed or only briefly mentioned in prominent anthropological works like Roxana Waterson, The Living House: An Anthropology of Architecture in South-East Asia (Singapore: Oxford University Press, 1990); 
Janet Carsten and Stephen Hugh-Jones, (eds, About the House: Lévi-Strauss and Beyond (Cambridge: Cambridge University Press, 1995); Mari-Jose Amerlinck, Architectural Anthropology (London: Bergin \& Garvey, 2001); Victor Buchli, An Anthropology of Architecture (London: Bloomsbury, 2013); or Tim Ingold, Making: Archaeology, Anthropology, Art and Architecture (London: Routledge, 2013).

${ }^{46}$ Oliver took around $25,00035 \mathrm{~mm}$ slides and photographs during his career. The images form part of the Paul Oliver Vernacular Architecture Library (POVAL), which is a Special Collection in the Main Library of Oxford Brookes University. Around 22,500 35mm slides have been digitised and are stored on Oxford Brookes University's Research Archive and Digital Assets Repository (RADAR).

${ }^{47}$ Marcel Vellinga, Architecture for All: The Photography of Paul Oliver (Oxford: Paul Oliver Vernacular Architecture Library, 2015).

${ }^{48}$ O'Connell, Blues, How Do You Do?

${ }^{49}$ Paul Oliver, African Shelter (London: Arts Council of Great Britain, 1975); Paul Oliver, English Cottages and Small Farmhouses (London: Arts Council of Great Britain, 1975). Oliver also curated an exhibition on the bazaar at Isfahan, Iran, which was on show at Dartington College in the mid-1970s.

${ }^{50}$ Oliver, "The Anthropology of Shelter", 9.

${ }^{51}$ O'Connell, Blues, How Do You Do?

${ }^{52}$ Oliver, "The Anthropology of Shelter", 13.

${ }^{53}$ Oliver, "The Anthropology of Shelter", 11.

${ }^{54}$ Oliver, Shelter and Society, 14.

${ }^{55}$ Paul Oliver, "Handed Down Architecture: Tradition and Transmission", in Jean-Paul Bourdier and Nezar AlSayyad, eds, Dwellings, Settlements and Tradition: Cross-cultural Perspectives (Lanham MD: University Press of America, 1989), 53-75; Paul Oliver, "Technology Transfer: A Vernacular View", in Raymond J. Cole and Richard Lorch, eds, Buildings, Culture and Environment: Informing Local and Global Practices (London: Blackwell, 2003, 246-268.

${ }^{56}$ This tendency is reflected in the Encyclopedia, which includes a separate section on "Westernisation" (Oliver, Encyclopedia, 121-122).

${ }^{57}$ O'Connell (2015) notes a similar tendency with regard to Oliver's blues writings, in which a clear distinction is created between early, "authentic", black and folk blues and later, commercialised, white, popular versions.

${ }^{58}$ For example, Oliver, David and Bentley, Dunroamin: The Suburban Semi; Oliver and Hayward, Architecture: An Invitation.

${ }^{59}$ For example, Clark E. Cunningham, "Order in the Atoni House", Bijdragen tot de Taal-, Land- en Volkenkunde, no. 120 (1964): 34-68; Pierre Bourdieu, "The Berber House", in Mary Douglas, ed., Rules and Meanings: The Anthropology of Everyday Knowledge (Harmondsworth: Penguin, 1973), 98-110; Gregory Forth, Rindi: An Ethnographic Study of a Traditional Domain in Eastern Sumba (The Hague: Nijhoff, 1981).

${ }^{60}$ Johannes Fabian, Time and the Other: How Anthropology Makes its Object (New York: Columbia University Press, 1983); George E. Marcus and Michael M.J. Fischer, eds, Anthropology as Cultural Critique: An Experimental Moment in the Human Sciences (Chicago: University of Chicago Press, 1986); James Clifford, The Predicament of Culture: Twentieth-Century Ethnography, Literature, and Art (London: Harvard University Press, 1988); Daniel Miller, Material Culture and Mass Consumption (Oxford: Basil Blackwell, 1987); Alfred Gell, Art and Agency: Towards a New Anthropological Theory (Oxford: Clarendon Press, 1998); Tim Ingold, The Perception of the Environment: Essays in Livelihood, Dwelling and Skill (London: Routledge, 2000).

${ }^{61}$ In 2003, Oliver received an MBE in recognition of his "contribution to architectural education".

62 Janet Carsten and Stephen Hugh-Jones, eds, About the House: Lévi-Strauss and Beyond (Cambridge: Cambridge University Press, 1995); Rosemary A, Joyce and Susan D. Gillespie, eds, Beyond Kinship: Social and Material Reproduction in House Societies (Philadelphia: University of Pennsylvania Press, 2000); Mari-Jose Amerlinck, Architectural Anthropology (London: Bergin \& Garvey, 2001); Victor Buchli, An Anthropology of Architecture (London: Bloomsbury, 2013).

${ }^{63}$ Notable exceptions include Trevor Marchand, The Masons of Djenné (Bloomington: Indiana University Press, 2009); and Tim Ingold, Making: Archaeology, Anthropology, Art and Architecture (London: Routledge, 2013).

${ }^{64}$ It should be noted, however, that UG and PG courses on architecture have been taught in recent years at a number of anthropology departments, including UCL, SOAS and Aberdeen. 